\title{
The Modern Lesson of Literature Arrangement with Regard to the Modality Characteristics of the Students
}

\author{
R. F. Mukhametshina ${ }^{1} \&$ T. V. Akhmatova ${ }^{2}$ \\ ${ }^{1}$ Kazan Federal University, Kazan, Russia \\ ${ }^{2}$ Municipal autonomous educational institution “Boarding School № 7”, Kazan, Russia \\ Correspondence: R. F. Mukhametshina, Kazan Federal University, Kazan, Russia. E-mail: zin-zulya@mail.ru
}

Received: March 5, 2015 Accepted: April 23, 2015 Online Published: September 24, 2015

doi:10.5539/ies.v8n10p13 URL: http://dx.doi.org/10.5539/ies.v8n10p13

\begin{abstract}
The article presents psychological and pedagogical research in the sphere of methodology of teaching Literature. It reveals theoretical aspects of consideration of the modality characteristics of the students, from the point of view of the structure of the up-to-date lesson. The topicality of the research is in taking into consideration sensor types of perception of the material studied, which contributes to a better quality of learning and motivation of learners.

The article shows the results of the ascertaining experiment, aimed at the detection of dominating perceptive modality of the $10^{\text {th }}$ graders of the Municipal autonomous educational institution “Boarding School № 7”, Kazan. This experimental research allowed the authors to come to the conclusion about the necessity of reconsideration of the methods of teaching students with different types of perception. The 'Methods and Pedagogical techniques' paragraph describes the ways allowing to individualize the process of studying a literary work, taking into account the modality characteristics of the students.
\end{abstract}

Keywords: modality characteristics, active techniques, learners' motivation

\section{Introduction}

A man as a personality is determined by the socium, and as an individual-by the psycho-physiological potential. Therefore, it is very important for the teacher in the learning process to take into account the peculiarities of educational material perception by the students.

In modern psychology we distinguish the types of students with regard to their modality characteristics (audiles, visuals and kinesthetic) associated with the dominance of certain areas in the brain (A. R. Luria). Modality determines the peculiarities of the cognoscible objects of the world symbolization by a man. Assimilation of the symbolic function, as shown by the recent studies, influences, for example, the effectiveness of skills in various activities development (Veraksa, 2014; Gorovaya, 2014; Grushko, 2014; Bayanova, 2014; Khabutdinova \& Rakhimova, 2014). Basing on the Luria's (1978) concept it is arguable that depending on the dominance of one of the hemispheres a man uses different strategies for handling verbal-logical and visual-spatial information (Moskvin, 1990). Theoretical analysis of the literature in the field of neuro-pedagogy allows revealing the following features in the behavior of students with regard to their perceptual modality in conditions of the today's lesson (Grinder, 2001).

Thus, the excellent assimilation of what has been seen and not heard is characteristic of the visuals, organized power of observation, emotional balance, imaginative thinking; audiles easily repeat what has been heard, they are distracted, experience difficulties while working in the noise, sociable, open to debate; kinesthetic are better trained in activities, remember general impressions of the event quite well, respond to physical incentives, etc. Thus, in view of the foregoing, there occurs the necessity of consideration of the cognitive characteristics of students in the arrangement of the lesson, which in turn leads to the need for us in different learning styles according to the different strategies of thinking.

\section{Methods}

To better understand the relevance of this approach, we have conducted ascertaining experiment allowing identifying the dominant types of the students' perception. 
Before we turn to the description of the procedure and methods of studying of the leading channel of perception, let us consider the methodological basis of our research. The analysis of literature on the problem of polymodality of perception of the subjects of the educational process allows us to make a conclusion that the question of sensory perception has been researched by the national academic, social and pedagogical psychologies. The modality of perception is considered (Ananiev, 1982; Bandurka, 2005; Barabanzshikov, 2006) as structural components of the sensory and perceptive organization and specially structured psychological formations, which influence the individual development of a person; they are the active components of their behavior and become apparent in their activity, including learning activity. At the same time there are still some unsolved problems in the research of sensory perception of the subjects of the educational process. The topicality of our experimental research of polymodality of perception of the subjects of the educational area is defined by insufficient working out of psychological problems of diagnosing and taking polymodality of perception of the subjects of the educational process into consideration while constructing a lesson.

The two classes (Class 9 A ad 9 B) of the "Boarding school No 7", Kazan, became the object of the study. For the purposes of modality characteristics study we have used the work "Diagnostics of the dominant perceptual modality" by Efremtseva. 41 trainees were involved in the experiment. The results of the study are shown in Table 1 and Diagram 1:

Table 1. Perceptive modality diagnostics of the 9 th grade students

\begin{tabular}{lllll}
\hline Class 9 A & Visual & Audile & Kinesthetic \\
\hline 11 & Kamil Abzalitdinov & 8 & 5 & 9 \\
22 & Ildan Bulatov & 9 & 9 & 10 \\
33 & Vladislav Bychkov & 12 & 8 & 9 \\
44 & Bulat Gainullin & 8 & 8 & 8 \\
55 & Marsel Garipov & 6 & 9 & 10 \\
66 & Iskander Ibatullin & 3 & 5 & 6 \\
77 & Yevgeniy Kiva & 11 & 12 & 12 \\
88 & Timur Mishagin & 6 & 11 & 7 \\
99 & Khaidar Mukhametzyanov & 9 & 6 & 7 \\
110 & Gadel Mukhametshin & 10 & 9 & 8 \\
111 & Bulat Nabiullin & 8 & 9 & 9 \\
112 & Aydar Sadiykov & 6 & 8 & 5 \\
113 & Almaz Samatov & 11 & 7 & 11 \\
114 & Egor Sychugov & 10 & 10 & 8 \\
115 & Rodion Turundayev & 11 & 10 & 11 \\
116 & Azat Umerov & 12 & 9 & 9 \\
117 & Nikita Ustyantsev & 8 & 10 & 10 \\
118 & Irek Fasylsyanov & 11 & 10 & 9 \\
119 & Salavat Fatiykhov & 7 & 9 & 7 \\
220 & Iskander Khabibullin & 8 & 10 & 8 \\
221 & Airat Khairullin & 9 & 9 & 8 \\
222 & Ayaz Shaikhutdinov & 4 & 9 & 6 \\
223 & Iskander Shameev & 9 & 11 & 8 \\
\hline 9 B grade & & & \\
\hline 11 & Aidar Abdulkhakov & 6 & 10 & 8 \\
22 & Insaf Abdullin & 10 & 8 & 9 \\
\hline & & & & \\
\hline
\end{tabular}




\begin{tabular}{lllll}
\hline 33 & Dinar Agleev & 12 & 12 & 8 \\
44 & Timur Gataullin & 9 & 8 & 11 \\
55 & Aibulat Dautov & 5 & 5 & 9 \\
66 & Rushan Zakirov & 9 & 8 & 6 \\
77 & Danil Zaitsev & 11 & 10 & 9 \\
88 & Timur Malikov & 9 & 9 & 8 \\
99 & Fatikh Manapov & 6 & 6 & 6 \\
110 & Aidar Mulyukov & 6 & 11 & 8 \\
111 & Ainur Mustafin & 9 & 8 & 7 \\
112 & Nail Nuriyev & 4 & 8 & 8 \\
113 & Insaf Nabiullin & 7 & 3 & 7 \\
114 & Bulat Nasibullin & 9 & 6 & 7 \\
115 & Irek Siraziyev & 11 & 10 & 6 \\
116 & Dinar Sitdikov & 11 & 8 & 9 \\
117 & Abdulazis Sabitov & 10 & 8 & 8 \\
118 & Airat Khalilov & 10 & 8 & 8 \\
\hline
\end{tabular}

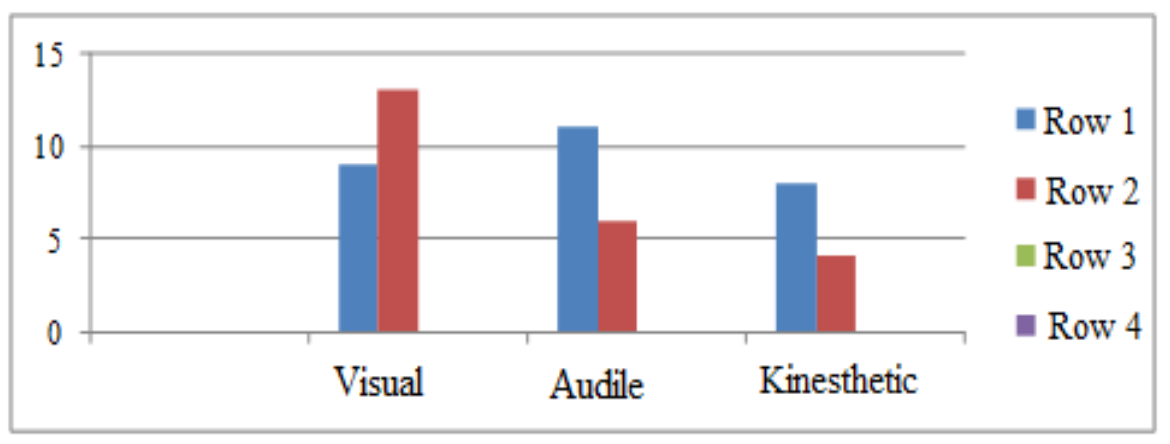

Diagram 1. Perceptive modality diagnostics of the 9 th grade students

The results of the experiment manifest that the audile perception type prevails in Class 9 A, and the visual perception type-in Class 9 B. $78 \%$ of recipients possess all practically equally developed perceptive modality levels. $22 \%$ of the students manifest disproportional development of the perception channels, primarily the visual and audile.

Thus, the conducted research allows affirming that for the purposes of learning incentives and increasing in the quality of education it will be necessary to apply different methods of training with consideration of perceptive modality at the Literature lessons in the classes under study.

\section{The Main Part}

The modern lesson, including the Literature lesson, shall be arranged in compliance with the Federal State Educational Standard (FSES); herewith the individual features of students must be considered, among them the language of education (Mukhametshina \& Galimullina, 2014).

B. Blum's taxonomy has laid the foundation for the educational results in compliance with the new standards, which is divided into six categories of educational goals: knowledge, understanding, application, analysis, synthesis and evaluation. Relying on the taxonomy of goals or on the Gardner's theory of the intellect multiplicity you can arrange tasks with consideration of the student's modality type. The Table No2 represents the Constructor of tasks reflecting the peculiarity of the task formulation for students with different types of educational material perception: 
Table 2. Constructor of educational tasks with consideration of modality type

\begin{tabular}{|c|c|c|c|}
\hline \multirow{2}{*}{ Educational tasks } & \multicolumn{3}{|c|}{ Educational tasks with consideration of the modality type } \\
\hline & Audile perception & Visual perception & Kinesthetic perception \\
\hline $\begin{array}{l}\text { Knowledge (of definite } \\
\text { material, terminology, } \\
\text { facts, determinations, etc.) }\end{array}$ & $\begin{array}{l}\text { Retell the work in details, } \\
\text { name the characters }\end{array}$ & $\begin{array}{l}\text { Make the schematic plan } \\
\text { of the work, explain, } \\
\text { illustrate, etc. }\end{array}$ & $\begin{array}{l}\text { Discuss in the group, tell } \\
\text { about the feelings, which } \\
\text { you experienced during } \\
\text { reading, etc. }\end{array}$ \\
\hline $\begin{array}{l}\text { Understanding } \\
\text { (description, } \\
\text { interpretation, etc.) }\end{array}$ & $\begin{array}{l}\text { Tell in your own words, } \\
\text { make questions to the } \\
\text { text, give the oral } \\
\text { characteristics to the hero }\end{array}$ & $\begin{array}{l}\text { Illustrate the idea of the } \\
\text { work, episode, make a } \\
\text { table, draw an oral picture } \\
\text { of a hero }\end{array}$ & $\begin{array}{l}\text { Dramatize the episode, } \\
\text { make a pantomime }\end{array}$ \\
\hline $\begin{array}{l}\text { Application (application } \\
\text { of information in the new } \\
\text { situation) }\end{array}$ & $\begin{array}{l}\text { Write annotation to the } \\
\text { book }\end{array}$ & $\begin{array}{l}\text { Make a wallpaper, } \\
\text { presentation, etc. by the } \\
\text { book }\end{array}$ & $\begin{array}{l}\text { Tell about the book in the } \\
\text { body language }\end{array}$ \\
\hline $\begin{array}{l}\text { Analysis (of interrelation, } \\
\text { principles of arrangement } \\
\text { etc.) }\end{array}$ & $\begin{array}{l}\text { Put together the intrigues, } \\
\text { heroes, problematic of the } \\
\text { work }\end{array}$ & $\begin{array}{l}\text { Make an advertisement } \\
\text { for the book }\end{array}$ & $\begin{array}{l}\text { Think how you could } \\
\text { have settled in reality the } \\
\text { problems under } \\
\text { consideration in the work }\end{array}$ \\
\hline $\begin{array}{l}\text { Synthesis (Development } \\
\text { of the plan and the } \\
\text { possible action system } \\
\text { etc.) }\end{array}$ & $\begin{array}{l}\text { Hold discussion on the } \\
\text { book, express your } \\
\text { opinion, make a test }\end{array}$ & $\begin{array}{l}\text { Invent the continuation of } \\
\text { the book, watch a play } \\
\text { and a film and compare } \\
\text { them with the book }\end{array}$ & $\begin{array}{l}\text { Make a poem about the } \\
\text { book, a dance showing } \\
\text { your understanding of the } \\
\text { book }\end{array}$ \\
\hline $\begin{array}{l}\text { Evaluation (judgment on } \\
\text { the basis of the available } \\
\text { data, opinion on the basis } \\
\text { of the external criteria } \\
\text { etc.) }\end{array}$ & $\begin{array}{l}\text { Write the composition, } \\
\text { review }\end{array}$ & $\begin{array}{l}\text { Think, how you could } \\
\text { illustrate the book, give } \\
\text { your evaluation of the } \\
\text { illustrations to the work }\end{array}$ & $\begin{array}{l}\text { Read the works of your } \\
\text { classmates, give your } \\
\text { estimation }\end{array}$ \\
\hline
\end{tabular}

Basing on the offered Constructor of tasks, let us consider separate methods of teaching literature for the visuals, audiles and kinesthetic.

Traditional teaching methodology involves the use of reproductive educational methods with consideration of modality characteristics of students-verbal, visual and practical-among which the dominant are presentation of the material in the form of lecture, retelling, the visual imagery at the lesson, different types of reading. Modern requirements of FSES (Federal State Educational Standard) defining competence-based approach to the construction of the lesson are aimed at the realization of independent activity of students. Therefore, the main task of the teacher-is the creation of an active learning environment. Referring to the work experience, we can say that any traditional methods associated with different learning styles, can be put into practice by means of active forms and techniques.

As a rule, the lessons of literature assume the study of biography, works of the writer, analysis of the book, the study of literary terminology. Traditionally biographical and literary material is studied in the classroom lectures. Let us consider how these lessons can be constructed in terms of modality characteristics of students. For example, in the study of the art movement the visuals can be offered the following tasks: to get acquainted with a text material containing information about the movement, complete the table basing on read material:

Table 3. Artistic direction

\begin{tabular}{|c|c|c|}
\hline \multicolumn{3}{|c|}{ Background of appearance of the artistic trend, historical basis } \\
\hline Aesthetic principles & & background \\
\hline Genres & Representatives & Works \\
\hline
\end{tabular}


On the whole, graphic organizers are efficient at the different stages of the work study by the visuals, as they help to build the image of the subject, arrange the ties between the new material and the previously studied one, foster the ideas generation, and help to systematize the material. Here, we think the method of the "Conceptual table" is interesting enough; we use it very often by making characteristics of the heroes in the book. The example of such table could be-the characteristic of Marya Bolkonskaya and Natasha Rostova, the heroines of the novel "War and Peace" by Leo Tolstoy:

Table 4. Line comparison

\begin{tabular}{lcc}
\hline Natasha Rostova & $\begin{array}{c}\text { Lines of } \\
\text { comparison }\end{array}$ & Marya Bolkonskaya \\
\hline $\begin{array}{l}\text { Black-eyed, homely girl with big mouth } \\
\begin{array}{l}\text { Abundance of emotionally colored speech, } \\
\text { which emphasizes Natasha's lyricism }\end{array}\end{array}$ & portrait & speech \\
$\begin{array}{l}\text { Love of nature, of music } \\
\text { She gives the horse-carts to the wounded } \\
\text { soldiers and is distressed for them } \\
\text { Maternity-is a main Natasha's destiny }\end{array}$ & $\begin{array}{c}\text { interests, ideals } \\
\text { A lot of words with positive colors, which says } \\
\text { about the kindness of the heroin } \\
\text { Care of the close people, striving to sacrifice } \\
\text { the life for their sake }\end{array}$ & $\begin{array}{c}\text { She does not want to come over to the side of } \\
\text { the Frenchmen hiding from the peasants' riot } \\
\text { Finds her happiness with Nikolay Rostov, } \\
\text { brings up her son Andrey. }\end{array}$ \\
\hline
\end{tabular}

Without any doubt, visual expression must be present at the lessons with the visuals, since the construction of knowledge in this group of students takes place through the creation of images. Work with video sequence and other visual teaching aids can be arranged with the help of the method "Look-Think-Be surprised". For example, for the study of classicism the students are offered the video and audio sequence (architectural and garden constructions, works of artists, and for background music-symphony). The result of work-identification of regularities basing on what has been seen. The teacher can offer to the weaker students with a misbalance of visual and audio perception, a cliché for building a complete answer. In general, a teacher should better to use a card-tips, signal words and images to visualize the poem for its memorizing for the visuals to learn the literary terminology.

For children with audile type of perception it is recommended to use other methods and forms of work. Of course, verbal teaching methods (lectures, discussions, etc.), reading aloud, debates et al will dominate among them. Let us consider some of them in more detail. So, biographical, review material can be studied by audiles using verbal techniques, lectures in particular. In our practice we use the lecture with stops suggesting little heuristic conversation after the presentation of the lecture material, we use the "The question for one minute" technique. The emotional impact is very important for audiles, thus, to intensify their speech activity, it is necessary to ask questions focused on the search for answers (for example-Why Natasha Rostova cannot be happy with Andrey Bolkonsky? Did Raskolnikov's theory help to change the world?).

Of course, it is better to use techniques related to the construction of word associations, based on steady semantic relationships for students with audile type of perception, to enhance their verbal and cogitative activity. In order to develop students' inductive reasoning in literature classes can use the technique of "Inductive Thinking Model". The students are asked to write word-associations on blank cards, and then after a joint discussion in the group they are arranged, and the principles of classification are determined. You can begin the study of artistic work using this structure identifying the lines of further analysis. For example, in the early acquaintance with the work of A. T. Tvardovsky "Distance after distance" (“За далью даль”) students are asked to write the words that are associated with the word "distance". Such work allows the students already at the beginning of the work to understand what this word gets several meanings in the text of the poet: "time", "space", "historical past of the country", "memory". All associations are confirmed in the process of textual analysis of the poem chapters. With the help of this structure you can investigate the causes of the murder by Raskolnikov of the old moneylender. In this case the technique allows to perfectly combining active analytical and verbal activities.

The work of kinesthetic in literature classes can be organized interesting enough as well. This category of students is characterized by practical, experimental, project activity, modeling and demonstration. E. A. Genike offers such methods for the work of kinesthetic as "Time-table: from causes to consequences", "Cubing", 
"Creative dramatization" and others. Consider the use of certain methods in literature classes. The method of "Time-table: from causes to consequences" is effective in the classroom analysis of artistic work, image system, for example, in the study of the images of Prince Andrey and Pierre Bezukhov, the heroes of the novel "War and Peace". The first step in the implementation of the method-the image of the time-table as a line with records: over it-"What happened?", under it-"Why?". One of the life periods of the hero acts as the object of analysis. Pupils list the actions of the heroes; they find out the reasons for their occurrence. This work can be completed by the method of "Empathy" (Khutorskaya, 2012), by which the student tells of the hero getting into his character. The student's response will be more vivid, emotional, if his classmates ask counter-questions activating the reader's experience of the answering student.

Making the compendia of lessons the teacher must remember that kinesthetic need movement, so all structures of Class building of the strategy Cooperative Learning are able to activate the learning activities of students in this category, which are best revealed while working in pairs and groups.

The method of "cubing" can certainly be applied in work with all categories of students, but it is most effective with kinesthetic, who prefer a work in groups and a live communication process. This technique involves activation of all types of intellectual activity in the classroom according to Bloom's taxonomy. Consider the example of tasks that can be indicated on the faces of the cube as applied to the lessons of literature devoted to the study of the Battle of Borodino in the L.N. Tolstoy's novel "War and Peace":

- Remember that you know from the history of the Battle of Borodino;

- Compare the pictures of the war 1805-1807 battles with the Battle of Borodino in the novel "War and Peace".

- Find the link between the picture of military activities during the battle and the description of the landscape.

- Draw a Venn diagram "Pierre at the Rayevsky battery"

- Express your opinion about the behavior of Napoleon and Kutuzov during the battle

- Think of what helped the Russians, according to Tolstoy, to win in the battle of Borodino.

\section{Results}

Within the framework of the experimental research of the differentiation approach to teaching at Literature lessons we also researched the dynamics of the quality of learning of the motivating component of the learning activity in two experimental classes (41 students), taught on the basis of differences in the modality characteristics. The analysis of the forming experiment allows to state, that putting into practice our devised methods contributes to the creation of the active learning environment for the learners with different types of perception, along with the increase in the quality of knowledge and motivation to learn:
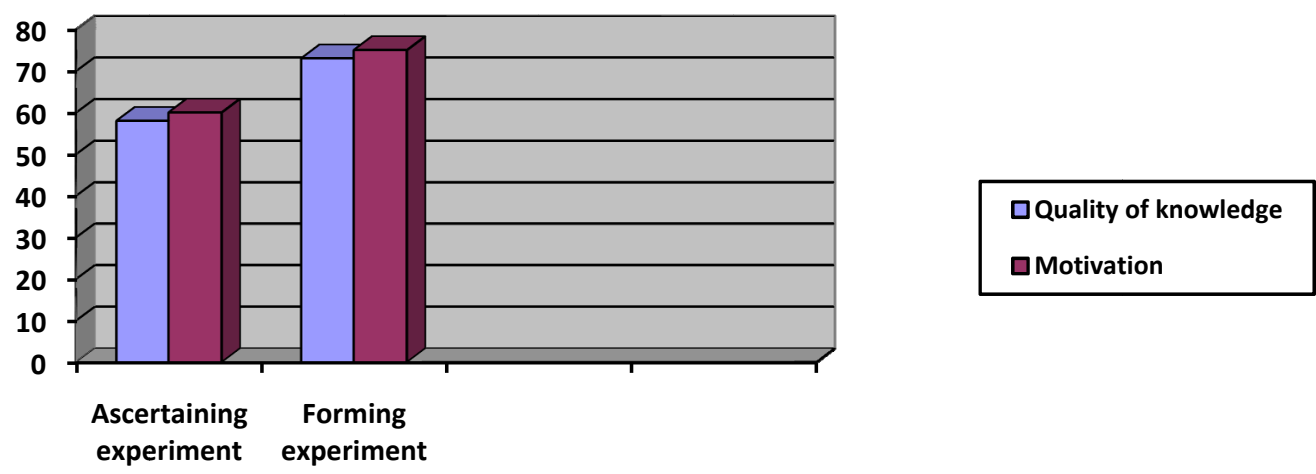

Diagram 2.

\section{Conclusions}

Thus, our research shows that the teacher must take into account the modality of every student to perceive and process information, "broadcast" information through the different sensory channels using an individual 
approach and a variety of teaching methods: both verbal visual, and practical.

The work is performed according to the Russian Government Program of Competitive Growth of Kazan Federal University.

\section{References}

Ananiev, B. G. (1982). Sensory-perceptive organization of a person. Cognitive processes: Sensation, perception (pp. 9-31). Moscow, Pedagogics.

Bandurka, T. N. (2005). Polymodality of perception in teaching: How to broaden the limits of cognition. Irkutsk: Ottisk.

Barabanszhikov, V. A. (2006). Psychology of perception: Organization and evolution of the perceptive process. Moscow: Cogito-Centre.

Bloom, B. S. (1956). Taxonomy of educational objectives: The classification of educational goals: Handbook I, cognitive domain. New York: Longman.

Bonwell, C. C., \& Eison, J. A. (1991). Active Learning: Creating Excitement in the Classroom. Higher Education Report, 1.

Buehl, D. (2008). Classroom Strategies for Interactive Learning (3rd ed.). IRA, Newark.

Genike, E. A. (2014). Aktivnye metody obrazovaniya: Noviy podkhod. Moscow: Natsionalniy knizhniy tsentr, IF "Sentyabr".

Grinder, M. (2001). Ispravlenie shkolnogo konveera. Moscow: Institut obshchegumanitarnykh issledovaniy.

Jensen, E. (2000). Brain-Based Learning. San Diego: Brain Store Incorporated.

Kabardov, M. K., \& Matova, M. A. (1988). Mezhpolusharnaya assimetriya i verbalnye i neverbalnye komponenty poznavatelnykh sposobnostey. Voprosy psikhologii, 6, 106-115.

Kagan, S. (2002). Cooperative Learning. San Juan Capistrano.

Khutorskiy, A. V. (2012). 55 metodov tvorcheskogo obucheniya: Metodicheskoe posobie. M.: Izdatelstvo "Eidos", Izdatelstvo Instituta obrazovanie cheloveka.

Luriya, A. R. (1978). Funktsionalnaya organizatsiya mozga. In A. A. Smirnova, A. R. Luriya, \& V. D. Nebylitsyna (Eds.), Estestvenno-nauchnye osnovy psikhologii (pp. 109-139). Moscow: Pedagogika.

Moskvin, V. A., \& Moskvina, N. V. (2002). Neiropedagogika kak prikladnoe napravlenie pedagogiki I differentsialnoy psikhologii. Vestnik OGU, 1, 34-39.

Mukhametshina, R., \& Galimullina, A. (2014). Inculcation of bimental personality in context of cultural dialogue (as exemplified by Tatarstan schools). Middle-East Journal of Scientific Research, 20(12), 2135-2138.

Veraksa, A., Gorovaya, A., Grushko, A., Bayanova, L., Melyausha, G., \& Dinara, G. (2014). Development and reliability of the Russian version of "The Sport Imagery Questionnaire". Anuario de Psicologia, 44(1), 45-54.

\section{Copyrights}

Copyright for this article is retained by the author(s), with first publication rights granted to the journal.

This is an open-access article distributed under the terms and conditions of the Creative Commons Attribution license (http://creativecommons.org/licenses/by/3.0/). 